\title{
Voces de la marginalidad
}

\section{en Lo amador, de Roberto Burgos Cantor}

Voices of marginality in Lo amador, of Roberto
Burgos Cantor

Hernando Motato C.*

Universidad Industrial de Santander, Colombia

DOI: http://dx.doi.org/10.15648/c1.25.2017.4

* Magíster en literatura Latinoamericana, Pontificia Universidad Javeriana, de Bogotá. Profesor Titular Escuela de Idiomas, Universidad Industrial de Santander, Bucaramanga-Colombia. jhmotato@yahoo.com

\section{(c) (1) (2)}




\section{Resumen}

Este ensayo es una reflexión sobre los cuentos de Roberto Burgos Cantor incluidas en Voces de Lo amador (1980). Aquí, Burgos Cantor configura personajes del barrio marginal a partir de sus diferentes oficios y formas de vida. Estos cuentos recrean la ciudad a través de la música popular y la relación de los personajes con espacios citadinos, bien sea los patios de las casas o las calles. El narrador emplea largos monólogos y en ellos cuenta cómo nació el barrio y las ilusiones de sus personajes, como por ejemplo, el de una joven que aspira a salir de su pobreza con la música o el joven que tiene como propósito la actuación en el cine, pero fracasa debido a un accidente en el taller de mecánica. Todas las historias de los diversos personajes son contadas por medio de la memoria.

\section{Palabras clave}

Voces, marginalidad, ciudad, personajes y memoria.

\section{Abstract}

This essay is a reflection about the tales of Roberto Burgos Cantor included in Voices of Lo amador (1980), which is the configuration of the marginal neighbourhood characters through different jobs and lifestyles. These tales recreate the city through popular music and the relationship the characters bear to city spaces such as the house yards or the streets. The narrator uses long monologues through which he narrates the creation of the neighbourhood and the illusions of his characters such as the girl who aspires to escape from poverty through music or the young man who would like to act in films but fails due to an accident in a car shop. All the stories of the various characters are mediated by memory.

\section{Key words}

Voices, marginality, city, characters and memory. 
Lo amador (1980) es un libro de cuentos del escritor cartagenero Roberto Burgos Cantor (1948). En la primera edición del Instituto Colombiano de Cultura en coedición con la Universidad de Cartagena aparecen siete cuentos, los cuales son: Historias de cantantes, El otro, Era una vez una reina que tenía, Estas frases de amor que se repiten tanto, Aquí donde usted me ve, Los misterios gozosos y En esta angosta esquina de la tierra. Las ediciones de Editorial Norma (2001) y Editorial Amaral (2012) conservan el número de cuentos de la primera edición; en cambio la Editorial Oveja Negra (s/f) le agrega cuatro cuentos, que son: Cuando el salitre destroza las palabras, La ceniza de los sueños, Violeta verde mar y sin nombre y Esta noche de siempre. Esencialmente, estos cuentos narran la vida de unos personajes sumidos en la pobreza social, excluidos de un bienestar social y dependiendo de la suerte de una rifa o de un viaje ilusorio a Venezuela. Los cuentos recrean la vida en el barrio pobre, de ese barrio que nace de los infortunios de la violencia, de ese espacio donde la miseria es la cotidianidad que abruma el espíritu de los personajes y solo la ilusión los alienta a una nueva posibilidad de cambio. De ahí que el canto se constituya en el aval para mantener el suspenso en alguno de los cuentos, pues una presentación en la radio, la composición de una canción o la prueba como cantante en Venezuela, mantienen en vilo el pensamiento y la vida de estos personajes, aunque al parecer ellos olvidan que están al margen de otra oportunidad sobre la tierra. De acuerdo con lo anterior, considero pertinente señalar que la marginalidad, tal como lo plantea el arquitecto y sociólogo, Fausto Martínez, es:

Fenómeno producido por la interacción de una pluralidad de procesos (o factores)... que afectan a los individuos y a los grupos humanos, impidiéndoles acceder a un nivel de calidad de vida decente y/o de participar plenamente según sus capacidades, en los procesos de desarrollo. Dichos procesos... conciernen a múltiples ámbitos: las dificultades de acceso al trabajo, al crédito, a los servicios sociales, a la instrucción, el analfabetismo, la pobreza, el aislamiento territorial, el riesgo epidemiológico, la discriminación por género, la discriminación política, las carencias de las viviendas y la discriminación étnico-lingüística. (2011, p.68)

Entonces, vemos cómo Mabel Herrera, personaje de "Historia de cantantes" vive ilusionada con su voz de cantante para que algún día sea reconocida y de dicho reconocimiento alcanzar la esquiva fama para solventar la precaria economía hogareña, dejada al desgaire por un padre que viaja a Venezuela con el fin de in- 
tegrar un conjunto musical, pero la dura realidad lo condena a mesero en un restaurante. Mientras tanto Mabel cuenta que: "Ahí ayudo a mi mamá con las rifas y con el reparto de la ropa a veces voy al programa de cantantes aficionados no sé si puedes cogerlo desde allá en la radio, es a las tres de la tarde" (Burgos, 1980, p.22). En esta cita observamos una redacción precaria, carente de puntuación, lo cual indica que este personaje tiene una escolaridad muy primaria, pero al mismo tiempo hay la intención de resaltar el mensaje de aliento a su padre.

Otra visión de la marginalidad está centrada en las voces o expresiones de su conciencia marginal, en tanto estos personajes asumen unas formas de comunicación, bien desde la oralidad, propia de la cultura Caribe, o bien desde la espacialidad, llámese barrio, en donde los personajes dirimen el conflicto de su existencia, a partir de oficios que condenan su procedencia y sentencian su vida a un destino trágico. De ahí que sea frecuente el uso de términos como "nojoda", "fijate", "aquí donde usted me ve", frases que el personaje ha arrancado de su entorno musical o festivo y pone en el fraseo diario con sus vecinos. En este sentido, Amir Valle descifra la situación del ser marginal en los recodos de la periferia cuando afirma:

Y es esta ciudad el escenario donde los protagonistas no pertenecen a esos seres que habitan (y hacen) la historia, sino a esos otros que la padecen y agonizan bajo sus oleadas usualmente devastadoras, según el hálito destructor de los nuevos tiempos. Prostitutas, asesinos, ladrones, pobres sin esperanza, jóvenes drogadictos y desilusionados de sus países y sociedades; habitantes, en fin, de los mundos oscuros de la perdición marginal, se convierten en los protagonistas de las historias literarias del presente de los años 90 y hasta hoy. (2007, p.98)

En tal sentido, este enfoque implica la presencia de unos personajes con una conciencia portadora de las quimeras que envuelven la pobreza; bien por el desplazamiento del campo a la ciudad, o de igual manera por la hondura existencial que les proporciona la vida cotidiana en los laberintos que encierra la ciudad a través de oficios del bajo mundo o de lo excluido del ambiente urbano. Precisamente, en "En esta angosta esquina de la tierra", el personaje cuenta que fue uno de los primeros pobladores del barrio. En un largo monólogo nos dice: "Yo en el barrio enseguida me acomodé no un acomodo de aquí llegué y tengo cogido a dios de una hueva no te suelto mira la creación el sexto día que te dormiste y la zorra hizo un desastre no un acomodo de ahí vamos sin sollarme en el desespero" 
(p.89) y con un estoicismo cargado de humor, nos deja la inquietud con la idea de que la resignación es la mejor compañía para soportar la pobreza y, por ende, la marginalidad.

Ahora bien, es necesario exponer o plantear que el uso del término marginalidad, en el análisis de una obra literaria, es tomado o en el mejor de los casos prestado de la sociología y de ella se toma la teoría de la marginalidad del sociólogo belga y sacerdote jesuita Roger Wakemans, quien fue uno de los principales exponentes de este concepto en América Latina. Para él, las sociedades de estos países son una "totalidad" y de ella el devenir de estas a partir de la verticalidad de la sociedad con las categorías de "afuera" y "adentro", "centro" y "periferia". En este caso, la ciudad concreta en los cuentos de Burgos Cantor es Cartagena y de esta ciudad aparece ficcionalizado el barrio Lo amador. Este barrio está ubicado en la zona norte de la ciudad de Cartagena, en las estribaciones del cerro de La Popa y colinda con los barrios Nariño, El Espinal y Toril. Como todos los barrios que nacen en la periferia de la ciudad colombiana, está poblado por gentes que en los años sesenta son desplazadas por la violencia partidista que azota el país debido a la muerte del líder liberal Jorge Eliécer Gaitán. El nombre del barrio se debe al apellido de un presidente de la asamblea del Estado Soberano de Bolívar; me refiero a Manuel Amador Fierro.

El desplazado se ubica, de acuerdo con los planteamientos de Amir Valle (2007), "afuera" o sea en la periferia de la ciudad, mientras el "adentro" corresponde a lo ya establecido por unas familias raizales ubicadas en torno a los apellidos de linaje y conservadoras de la tradición religiosa y cultural heredada de España. En cuanto al "centro", es ese espacio de lo tradicional y son esas familias que habitan la cuadrícula de la plaza. Sus casas aún ostentan el viejo escudo de familia, traído de España y tienen el privilegio de ir a la iglesia a cualquier hora del día y de ocupar los puestos del gobierno, los cuales son heredados de generación en generación. En síntesis, allí reside el poder, pues ese es el centro de la ciudad. Mientras en el "afuera" está el recién llegado, el advenedizo, aquel personaje expulsado del campo y desposeído de los beneficios que la ciudad ofrece y esto le otorga la triste denominación social de marginado; o lo que el renombrado sociólogo Sáenz O llama "la refundación traumática de la ciudad" y que consiste en que la periferia es el producto del crecimiento anárquico de la ciudad. Entonces, "Para comprender al marginal es necesario considerarlo como un hombre expulsado de su mundo de origen -el hinterland- no acogido por la urbe moderna, viviendo en la "tierra de nadie" y siendo definitivamente nadie en términos de significación social” (Hoffmann, García, Mercado y Uribe, 1969, p.285). Esa 
tierra de nadie, título apropiado de la novela de Juan Carlos Onetti, está relacionada con las características con las que están configurados los personajes de $L o$ amador, en tanto están al margen del centro de la ciudad, desprovistos de lo más elemental que la ciudad ofrece. Ante esta vida deplorable, asumen una actitud estoica que se manifiesta en la música y el baile o en oficios que la tragedia de vivir les ofrece. Burgos Cantor apela en este sentido al estribillo de una canción salsera. Es la voz de ese narrador anónimo que evoca su llegada a ese eriazo y el ganar un espacio para disfrutar de las canciones del Jefe Daniel Santos o de una guaracha.

Fíjate, siempre así, yo que nací cantando, cuando quería contar mi invención ya alguien me la había robado. Nojoda, yo no sé qué pasa, pero a mí como que me tocó este rinconcito del mundo donde todas las vainas ya pasaron. (1980, p.29)

La voz o conciencia del personaje muestra la capacidad para integrarse a un mundo sociocultural codificado por una serie de comportamientos marginales y en directa relación con la interiorización espiritual del excluido. De tal modo, la marginalidad, desde la perspectiva de la ciudad, en el caso de los cuentos de $L O$ amador (1980), está conformada por las historias de esos personajes que llegan a un sitio de la ciudad y allí resignifican su existencia de lo que les ofrece la marginalidad urbana: trabajos mal pagos, los golpes de una vida amarga y surcada por la "mala suerte", como ellos suelen llamar a la exclusión. En primera instancia, destaco la situación de violencia que propicia el éxodo de campesinos hacia la ciudad, y en ella, la necesidad de vivienda que propicia la ocupación o invasión de baldíos o de terrenos ejidos para construir sus precarias viviendas, pues es importante resaltar que la marginalidad depende de las diferentes situaciones y circunstancias que encuentren en la ciudad. Entonces,

... el ocupante de sitios eriazos o de casas aisladas, ubicado en forma dispersa en áreas urbanas desarrolladas, ya sea porque logró aislarse en medio del avance de nuevas construcciones o formación de zonas urbanas, dentro del proceso de urbanización creciente, fue agregado en calidad de cuidador de sitios, o simplemente porque invadió, individualmente, terrenos que encontró disponibles. (Hoffmann et al., 1969, pp.293-294)

Desde este punto de vista, la propuesta estética de Roberto Burgos Cantor sobre las expresiones de la marginalidad consiste en contar cómo la ciudad crece en 
el caos de la vida del barrio pobre y para ello se vale de las expresiones de la cultura popular, como son: la música y en ella las letras de los boleros y la Salsa, la oralidad y el humor. Con base en estas manifestaciones de la cultura popular, configura los personajes de sus cuentos en Lo amador, su obra prima -Burgos Cantor quiso llamarla Historias de Cantantes-; en donde el escritor define diversas formas de esos personajes marginales en un espacio ficcional, un barrio de la periferia de Cartagena, en donde desarrolla unos acontecimientos narrativos constituidos por unos personajes definidos por las voces de la costurera, la cantante frustrada, el mecánico, la bruja, oficios que definen unas formas de la vida marginal. Para la ficcionalización del espacio es necesaria la armonía entre personaje y ambiente, pues los cuentos trazan una línea sucesiva de comportamientos y formas de pensamiento de los personajes muy propios de su condición de personaje marginal. Dichos personajes aparecen derrotados por la vida, sin esperanzas de salir del barrio, anclados a las ilusiones de un futuro incierto y apegados a las letras de las canciones como única posibilidad de alegría. “... y se la pasaba, la noche entera en la sala al lado del RCA Víctor que prendía bajito para escuchar boleros de Daniel Santos..." (1980, p.43).

Con base en lo anterior, tenemos la configuración de los diferentes personajes que constituyen Lo amador: personajes que aparecen en un espacio donde construyen sus casas al margen de todas las exigencias y lujos que ofrece la vida urbana. Lo amador es el anuncio del crecimiento anárquico de la ciudad y un barrio colmado de tristezas. Los personajes testimonian cómo crece el barrio y cuáles son sus condiciones de vida al margen de la modernidad de la urbe. El nacimiento del barrio ensancha el devenir de sus personajes al margen de las comodidades, placeres y ostentaciones que puede ofrecer la ciudad. También es el barrio receptor de unos habitantes desplazados por los ecos de una violencia anclada en los rediles de la existencia. En el texto leemos:

Lo encontraron ya muerto en el parque que está frente a la cárcel de San Diego envuelto en una bolsa de plástico. Estaba tibio y como dormido. Debajo de la tetilla izquierda tenía un hueco pequeño y ennegrecido en los bordes. (1980, p.64)

Es otra expresión de la violencia. El narrador de un modo minucioso y descarnado describe al negro José Raquel, aquel trabajador del puerto que buscó todas las formas para salir de esa miserable condición de cargador de barcos, que estudió y se ganó el liderazgo y aprecio de sus compañeros por defender y reclamar sus justas peticiones. 
La condición socioeconómica de los habitantes del barrio Lo amador, nutre la percepción estética de Burgos Cantor en tanto él aprovecha todas esas expresiones de la población que trabaja en oficios artesanales o, podría decirse, informales para la estructuración de personajes y en ellos ese saber hacer y decir las cosas de la manera más sencilla y cotidiana como es la ocupación de la mamá de Mabel Herrera en el cuento "Historias de cantantes"; los mecánicos de automóviles, como Atenor Jugada en "El otro"; los cantantes frustrados, como el padre de Mabel y ella misma; los vigilantes, albañiles y carpinteros; esto sin mencionar la venta de rifas que se convierte en una manera de sobrevivir en los barrios populares de la ciudad naciente de los cuentos. "Atenor Jugada sobrevivía a sus encuentros con la desgracia. Parecía una lucha de la cual él salía revolcado y sonriente a buscarla de nuevo con la secreta seguridad de ganarle un día y amarrarla para siempre" (p.29). En esta cita desgracia y revolcado son dos palabras clave para entender la pobreza de este personaje y cómo asume la desgracia de un modo jocoso: amarrarla y ganarle.

Asimismo, con base en esta cita vemos que la marginalidad es la superposición de capas sociales en primera instancia. En este encuentro social, el desposeído lleva la peor parte, pues no vive sino que sobrevive la desgracia de ser marginal. En los cuentos de Lo amador esta situación la encontramos en la aparición de pobladores desplazados del campo que ingresan al crecimiento poblacional de la ciudad y aquí ocupan los predios periféricos, y como tal, carentes de los más elementales servicios públicos. Este desplazamiento obedece en muchas circunstancias a fenómenos de violencia o a las condiciones de pauperización del campo. Estos casos los asume la literatura y de ello dan cuenta, por ejemplo, los personajes orilleros de las llamadas "villas miserias" en los cuentos de Jorge Luis Borges, las muchachas del servicio y obreros venidos de las minas de cobre ubicados en "las callampas" chilenas de los cuentos de José Donoso; la vida atormentada de los personajes y las expresiones de violencia urbana de las "favelas" de Rio de Janeiro en los cuentos del escritor brasilero Rubem Fonseca y en la magistral novela Cidade de Deus, de Paulo Lins. En el caso de la obra de Roberto Burgos Cantor, aparecen personajes mulatos y negros con ocupaciones marginales, además de la ya mencionada modistería, también aparecen la pesca, la albañilería o la práctica de deportes como el boxeo. Esta apropiación de la vida marginal hace que la obra de Burgos Cantor sea sólida en un haz de personajes definidos en la historia social del negro, el tráfico negrero y el desarrollo de la ciudad colombiana. De ahí que los cuentos de Lo amador sean el germen de sus posteriores obras y se conviertan en los "vasos comunicantes" con los cuentos publicados en el libro De gozos y desvelos (1987), en donde también aparecen 
el boxeador, el pescador, la muchacha que llega de un pueblo de Córdoba y se emplea como muchacha del servicio y termina su vida en un prostíbulo. En esta misma línea, aparece la novela El patio de los vientos perdidos (1987), en donde el prostíbulo, junto con la música y el boxeo, es determinante en la vida de los personajes. Así se llega a su obra culmen: La ceiba de la memoria (2007), en donde se narra cómo llegan los negros a Cartagena y son despojados de su cultura, sus ideas y sus creencias. A ellos les imponen una tierra y unas formas de vida que trastocan sus pensamientos y condicionan una vida de sumisión y penurias.

En este orden de ideas, la ubicación del barrio en el espacio de la ciudad posibilita que sus personajes idealicen la ciudad desde la piel que se rasga en las calles, desde la memoria enamorada que en noches de luna idealiza a la mujer, desde las tardes en la contemplación del mar y el rumor que enamora a las parejas en la intensidad del amor. La ciudad es el pasado que se empoza en la memoria de sus personajes, tal como lo recuerda en su vejez la voz del personaje femenino, la mujer que llega al barrio con su oficio de leer las cartas de la baraja en el cuento "Aquí donde usted me ve". Ella cuenta el nacimiento del barrio y apela a un estribillo de la canción Bomba camará, de Richie Ray y Bobby Cruz: "Aquí donde usted me ve" (camará)/ yo soy el negro/más bravo... (camará)", y en ese juego entre la literatura y la Salsa, tal como lo hace magistralmente Burgos Cantor, la voz narradora nos cuenta cómo nace el barrio:

Aquí donde usted me ve cuando yo vine esto no era barrio ni era nada un deseo de seguir vivos y esa ilusión de un pedazo de patio con techo para cantar por la mañana para no dejarnos enfriar por ahí dejados de la gracia y con hambre era inventar de nada con puro deseo y ganas y los pocos que éramos estábamos todos. $(1980$, p.69)

"Aquí donde usted me ve" es el recurso al cual apela la narradora para la evocación de un pasado lleno de infortunios, penas y dolores que generan la pobreza y la marginalidad. Entonces, "Lo amador se desarrolla en un medio muy auténtico, es parecido al seno materno donde empiezan todas las historias..." (Aristizábal, 2009 , p.155). Es la memoria que cuenta el apego a las cosas desde el cómo se logró que el barrio creciera y apareciera el teatro, ese espacio único para la diversión de todos los personajes del barrio. Así apareció el teatro Laurina, nombre tomado de Laurina Emiliani Vélez, esposa de Vicente Martínez Martelo, alcalde de Cartagena, en cuyo honor se bautizó el teatro de Lo amador. Como señala Alonso Aristizábal al referirse a la estrecha relación entre espacio y memoria, a 
la convivencia entre pesares y necesidades, entre ilusiones y fracasos; los cuales son expresiones de la vida marginal en el barrio, "Los personajes de Lo amador tienen un código que les exige fidelidad al pasado" (2009, p.166).

Burgos Cantor escribe:

Aquí donde usted me ve cuando yo vine esto no era barrio ni era nada y el teatro Laurina durante sus dos primeros años seguía llenándose y cada tercer día cambiaban el programa el que más duró fue el del primer día porque la gente pedía que lo volvieran a pasar lo pasaron todo un mes y medio la primera película que vi en mi vida y siguieron con el pavimento para las calles: eso fue un discurso porque cuando tuvimos una reina ARACELY 1era nos tocaba andar a brincos y por tablones en los meses de lluvia o regar agua en la calle en los meses de verano para que el polvo no nos cambiara el color de las cejas... (1980, p.74)

En el oficio de recordar, el barrio se desdobla entre la ausencia de sus amigos muertos, como la mamá de Mabel Herrera, quien se suicida de nostalgia un 31 de diciembre por la ausencia de su esposo, un personaje que viaja a Venezuela en busca de fortuna como cantante; o la muerte violenta de Atenor Jugada, muerte de la que en el cuento "El otro" no se conoce el cómo o el por qué, pero que en la novela El patio de los vientos perdidos (1984) se relata que su causa social y solidaridad con los pobres están vinculadas con actos propios de la vida marginal como el robo: Atenor "era un man entero... Después el hombre se hundió en el desespero muy atacado por la vida y se soltó con la vaina de Pájaro Verde de robar y repartir la moneda entre la gente necesitada y le llegó la hora la mala" (1984, pp.13-14).

Atenor Jugada lucha con la existencia, aspira una nueva forma de vida, se ilusiona con las mujeres de las películas que ve en el teatro Laurina, sueña con paraísos de felicidad, pero la realidad es dura, "la calle está dura mi compay". El robo es una opción a sus desgracias, pero hasta en esto fue perdedor, y con la muerte terminan los infortunios que lo llevaron a la desesperación. Pero ante tanta adversidad, Atenor es el claro ejemplo de la marginalidad desde esa dimensión de la exclusión, tal como son los personajes de estos cuentos de Burgos Cantor.

Para este personaje, como para los otros personajes de Lo amador, no hay registro en las páginas sociales de los periódicos ni en la radio; la muerte es uno de los 
tantos marginales que la ciudad condena al olvido. Esos marginales solo se perpetúan por las evocaciones lastimeras de la bruja o en los recuerdos tristes que el esplendor de la memoria saca a flote. Es la voz de la lectora de cartas convertida en memoria histórica de su propia vida y de los personajes del barrio.

La escritura en Burgos Cantor es la savia del tiempo que actúa como principio germinativo, es decir, mediador entre todos los personajes que integran este núcleo de cuentos que referencian el sentido de la marginalidad. Entonces, la escritura apela a esa mujer que ha quedado olvidada en su vejez, una mujer consciente de la soledad y de su intento por recuperar el pasado: "Aquí donde usted me ve cada día más desmemoriada intento recordar y me siento sola ese solo que cubre los retratos con su amarillo hasta gastarlos..." (1980, p.75). Gracias a la memoria, el cuento regresa al comienzo y esto es clave para descifrar el sentido de sus evocaciones, pues ella repite y repite ese pasado de un modo incoherente. No obstante, en el cuento estas evocaciones aparentemente inconexas son el fluir de la conciencia y, de este modo, encontramos que el escritor apela al monólogo interior para dar comienzo al nacimiento de aquellos personajes que luego aparecen en De gozos y desvelos (1987) y en El patio de los vientos perdidos (1984); esto desde la coherencia narrativa, desde ese horizonte estético que traza la configuración de los diversos personajes de Lo amador y de las obras antes mencionadas. Es desde ese fluir de la memoria, que los personajes de Lo amador se desdoblan entre recuerdos y ausencias y su mundo vive en función de una ilusión pasajera, bien en el cine o en las letras de un bolero.

De lo anterior se puede inferir que otra forma de marginalidad se entiende a través de la condición espiritual del personaje cuando no puede dar fin a su condición miserable como sucede con Atenor Jugada, personaje que como mecánico "terminó abruptamente un mediodía con la caja de velocidades de un destartalado Chevrolet 23 sobre una pierna" (1980, p.27); o que como actor de cine nunca pudo alcanzar el éxito porque siempre lo remplazaron otros: "Eso es barro que a uno puedan reemplazarlo y confundirlo con cualquiera" (1980, p.29). Lo mismo sucede cuando comprende que ya no sería famoso como cantante, debido a que "los temas que decía inventar habían sido grabados antes por personas a quienes visitó primero la inspiración" (1980, p.27). Esto muestra que "Atenor Jugada nunca hizo cosa distinta a encontrarse con la desgracia" (1980, p.27); por consiguiente, Atenor es el personaje típico del barrio, el bacán, o sea: "Persona alegre, fiestera, complaciente, responsable y honesta" (Espinosa, 2010, p.37), definición que coincide con la del Diccionario de Americanismos, el cual dice que bacán es una persona agradable, amable, popular (2010, p.189). De ahí que Atenor ter- 
mine como ladrón, pero un ladrón al estilo de Robin Hood; pues su bacanería lo hace intensamente Caribe, lo hace un personaje solidario en la dimensión de sus carencias económicas, pero amplio en su abundancia de amor y bondad.

Por consiguiente, la marginalidad en los cuentos de Lo amador se expresa en la relación entre personajes y espacio urbano a partir de las formas como viven los personajes en su dimensión social, espacial y cultural. Tal es el caso de la fundación del barrio en un área periférica y habitada por unos personajes que viven al desgaire y llenos de ilusiones. En este sentido se ubica "Historia de cantantes", un cuento cuyos personajes son: el papá que salió loco de contento para Venezuela con la ilusión de ser cantante en un conjunto y desde allá alimenta, a través de cartas, la ilusión de su hija Mabel Herrera: “... al fin empecé como mesero nocturno no es lo que yo quería pero algo es algo y oigo las orquestas que se presentan con buenos cantantes" (Burgos Cantor, 1980, p.18); pero esto no es lo que él quería ya que su condición de desplazado social y, peor aún, su condición de colombiano en Venezuela empeoran su estadía y sus propósitos en este país; los cuales determinan su frustración.

Por otra parte está la madre, quien quiere que su hija sea modista y arma un castillo de cucañas con su taller:

MODISTERÍA

\section{CORTE Y CONFESIÓN}

En tanto Mabel Herrera aspira a ser cantante. Para ello escucha la música de los grandes artistas del momento, de ahí que "cuando entró sacudiéndose los pies ya estaba sonando el Benny en el radio con Santa Isabel de las Lajas querida que a ella le gusta mucho y dice que el Benny es asunto aparte que no necesita acompañamiento para cantar, aunque creo que eso se lo oyó decir a papá" (1980, pp.13-14), dice el narrador. Aquí la condición marginal está estrechamente ligada a su manifestación cultural con la música afroantillana y con ella, la presencia del cantante Bartolomé Maximiliano Moré, conocido artísticamente como Benny Moré (1919-1963), nacido en Santa Isabel de las Lajas, antigua provincia de Las Villas y actualmente perteneciente a Cienfuegos. La referencia a Benny Moré tiene que ver con su ascendencia negra, pues su facultad para la música es la "influencia decisiva para su futura carrera como músico, gracias a una cofradía de negros denominada Casino de los Congos o San Antonio, fundada por negros congos libertos provenientes de África central y occidental" (Santana, 1999, p.11). Entonces, la música no solo es expresión de unos momentos alegres, sino la exaltación de un pasado legendario y hoguera de una conciencia cultural surgi- 
da de la marginalidad; de ahí que la música afroantillana tenga un peso espiritual, cultural, religioso y, por ende, sagrado en la conciencia y expresión cultural de los negros. Esa música traída del África ya implica su condición de negro y su marginalidad. De este modo, Burgos Cantor establece una perfecta homología narrativa entre cantante y modista, basada en las aspiraciones frustradas de Mabel Herrera en este cuento de Burgos Cantor.

Ahora bien, el tratamiento de la marginalidad remite a las reflexiones sobre el desarrollo de la ciudad y cómo este propicia dos polos irreconciliables de vida urbana. Burgos Cantor capta muy bien estas contradicciones sociales de su ciudad natal a partir de las formas de vida que ofrecen sus personajes y las voces de su conciencia marginal. Ellos viven la ciudad en medio de unas condiciones de vida excluidas de los roles de vida urbana, pues para ellos la ciudad existe a través de lo que el barrio y sus calles ofrecen. Bien lo dice Alonso Aristizábal: "En Lo amador el aspecto más notorio lo constituye la vivencia diaria del barrio con su historia a través de sus calles, andenes, zaguanes, ventanas, y buses como lugares de encuentro de la amistad" (2009, p.155). La calle es el escenario de los juegos intensos de bola'e trapo, en ellas dos piedras hacen de arco y lo que importa es la gambeta. La calle es el espacio para que los niños con cuatro piedras como bases, un palo de escoba y una checas (tapas) disputen arduamente el partido de béisbol e imaginen que son los mejores right field, center field, los mejores lanzadores y su ilusión viaja al mundo de los Yankees de Nueva York o Los Medias Rojas, de Boston, entre otros. La calle es el lugar posible para el cortejo a las vecinas que pasean sus humildes pero seductores cuerpos morenos. La calle pone en escena las disputas de pretil a pretil, como diría David Sánchez Juliao, a las que hasta ese día eran amigas, la palabra enreda ofensas en medio de las figuras retóricas. En la calle se pasea el rumor de la joven que ya es señora o de la mujer "cachona".

Otro espacio de diversión es el teatro en donde los personajes apaciguan sus penas y dolores económicos. Este lugar les propicia encuentros con sus ídolos para la imitación. En términos de Ítalo Calvino podría decirse de la ciudad y sus signos que el teatro es el ícono de diversión y allí el ojo de los personajes "no ve cosas sino figuras de cosas que significan otras cosas: las tenazas indican la casa del sacamuelas, el jarro la taberna, las alabardas el cuerpo de guardia, la balanza el herborista" (1999, p.24). En Lo amador esos signos son: 1) las calles como el lugar donde se lucen las desgracias de la pobreza, pues en ellas las mujeres lucen sus raídos trajes, los niños la desnudez o la ambición de salir adelante a través de los puños y 2) los hombres y las nostalgias de su miseria en las letras de un bolero. 
De Calvino retomo la idea de la ciudad y el deseo. Para él, la ciudad aparece como un todo espiritual en el que ningún deseo se pierde y, en este sentido, la radio condensa el deseo de Mabel Herrera para sus pretensiones de cantante. La radio es la posibilidad inmediata para su formación, pues en ella escucha a sus cantantes preferidos y modelos de imitación: "mientras en el radio el locutor de la mañana invitaba a Mabel Herrera su mismitica hija al programa de los aficionados de la tarde" (1980, p.13).

Otra voz de la marginalidad se encuentra en el cuento "En esta angosta esquina de la tierra" el cual empieza con el estribillo de la canción de Nelson Pinedo "Me voy pa'La Habana", que dice así: "Yo no soy de por aquí yo soy muy barranquillero / Yo no soy de por aquí yo soy un barranquillero / Nadie se meta conmigo que yo con nadie me meto / Nadie se meta conmigo que yo con nadie me meto". La composición original es de José María Peñaranda que dice así:

\author{
Yo no soy de por aquí \\ yo soy de Barquisimeto \\ nadie se meta conmigo \\ que yo con nadie me meto. \\ Yo me voy pa'Cataca y no vuelvo más \\ el amor de Carmela me va a matar \\ (José Portaccio, 2004, p.173)
}

"Yo no soy de por aquí" es la voz de esa conciencia y memoria atormentada de ese personaje que en la ciudad maneja un destartalado bus desde el barrio Lo Amador hasta el centro, es la memoria conculcada por la violencia, los muertos y la vida difícil en la ciudad. Entonces tenemos al personaje salido del campo, asimilado a la vida urbana desde el ambiente de la marginalidad, pues él apela a la evocación para contarnos cómo llegó al barrio: "Apenas yo soy un man que se vino de un pueblo un pueblo que lo que más tiene es silencio y muertos y que se vino porque tiene miedo" (1980, p.93). La violencia y el desplazamiento fueron las estrategias del gobierno para el desplazamiento sistemático de los campesinos para el poblamiento acelerado y caótico de la ciudad colombiana. En este sentido, el personaje proporciona otra visión de la marginalidad, es el agente portador de una voz: la del desplazado que recuerda con nostalgia ese pasado en el campo, ese pasado de balas, muertos y miedos. Tal como lo plantea acertadamente Julio Olaciregui, con respecto a esas voces que se pierden en la soledad: "En medio de esas confesiones, de esos cuentos vocingleros, de esos textos para leer en voz alta, de esa alegría de narrar, se escucha también un silencio, un desconcierto, 
un dolor, la muda violencia del vivir, amar y matar o morir." (2009, p.180). Ese desplazamiento produce un encuentro de capas sociales, una subversión en la tranquilidad de los raizales y en los valores que se invierten ante la atónita aparición de grandes masas de campesinos sacudidas por la violencia partidista y la asunción de vocablos nuevos, de sentimientos e ideologías nuevas; desde esta perspectiva se entiende el sentido del final del cuento. En una pared aparecen los letreros con un alto sentido político y en donde se cruzan las consignas de izquierda como "Camilo vamos bien", con lo popular como "Aracely es la reina".

Otra voz de la marginalidad es el humor caribeño, o mejor, el mamagallismo, del cual García Márquez es el padre. Sobre el humor dice Macedonio Fernández $(1988$, p.122) que es esa exhibición de facultad de ingenio y su juego inofensivo con el lector. Esa facultad de ingenio se evidencia en el cuento "Los misterios gozosos". Se llama Onissa, dice el narrador, y cuenta la llegada de la muchacha de un pueblo remoto del Caribe y el encierro en una pieza en donde atiende a los clientes. Tal parece que el encierro, como todos los personajes de Lo amador, es el autocastigo que ella se impone a la desgracia de ser en el barrio: bruja, puta o santa, tal como la recuerdan. El título del cuento juega con el sentido de santa, de mujer piadosa, rezandera, tal como lo insinúa el título de los misterios gozosos, pero el goce del misterio está en su oficio de puta, pues cuando abren la pieza, al costado de la peluquería, encuentran: "estampas de arcángeles, santos, artistas de cine y cantantes, pegados con almidón, cubrían las paredes hasta el techo" (1980, p.79). El humor es juego con el lector, quien descifra la vida amarga de Onissa desde su encierro y desde la alusión a la música a través de esa letra del tango "Melodía de arrabal" que dice: "Barrio plateado por la Luna, rumores de milonga es toda mi fortuna". Aquí está el ingenio humorístico del escritor, pues apela al rumor, o como lo expresa Julio Olaciregui:

Quiso ante todo aprovechar la oralidad, la subversión del lenguaje popular, el humor, el erotismo de la gente de la calle, común y corriente como se dice, del pueblo, regresar a la ciudad de su infancia, al puerto, a los muelles, al mercado, a sus islas, meterse en los barrios donde viven las modistas, contar historias de muchachas que sueñan con ser cantantes, hablar de mecánicos, de ladrones, de sirvientas, de boxeadores, de putas. (2009, p.180)

La subversión del humor está en lo narrado por el periodista que cuenta a su antojo quién es Onissa, cómo llega al barrio y con quién la ven de noche. Es el poder de la palabra para la deformación de los recuerdos, es el juego con la pa- 
labra para la exageración de los hechos o para la consagración de la muchacha en su encierro y entrega a la oración. Todo lo anterior obedece a los códigos del honor, con el cual se invita a la reflexión, tal como se define el humor desde su condición filosófica.

La pulcritud es esa forma como el escritor teje de manera insospechada una red narrativa o un sendero de acontecimientos que, paso a paso, conduce la lectura a la cima máxima de su quehacer literario y esto es lo que sucede con los cuentos de Lo Amador. En ellos se encuentra al escritor pulcro en la manera como teje las historias marginales de sus personajes. Ya se ha señalado que los cuentos se prestan personajes, por ejemplo, Atenor Jugada pasa de "El otro" al cuento "Aquí donde usted me ve", y este mismo personaje aparece luego en la novela El patio de los vientos perdidos. Este breve retroceso amerita el sentido del cuento "Estas frases de amor que se repiten tanto", en tanto dichos personajes y sus voces de la marginalidad fraguan la estructura y el quehacer de los personajes. En este cuento hay un desarrollo paralelo de dos historias. La primera es el encierro en una alcoba del periodista con su amante, una joven universitaria, que participa en la muerte de José Raquel. Ella le cuenta los padecimientos de ella como carcelera de José Raquel y qué hacía él en el encierro: "Lo sentíamos en el piso de baldosas contra los pies descalzos cuando nos levantábamos en la oscuridad para buscar el baño del patio" (1980, p.53). Esos amaneceres húmedos, el abandono de los estudios por un ideal revolucionario, la fe ciega en la revolución, el sacrificio de la soledad e incomprensión, el temor y la temeridad para cometer un atentado o el desengaño de la misma por los actos violentos, son reflexiones que ella guarda en su memoria y que hacen necesaria una confesión. De ahí que al final del cuento considera que la catarsis ya ha aliviado su conciencia y eso le da aliento para la confesión más comprometedora de un secreto, pues le dice a su compañero que: "Hay algo que no te dije, por pudor tal vez, y es que yo no entiendo una militancia que no sirve para que la gente se encuentre y mejor que no nos dijimos lo de la violencia" (Burgos Cantor, 1980, pp.63-64).

En estas, las voces de la marginalidad abortan otra expresión en los personajes de Lo amador y son los brotes de rebeldía a partir de las ideas revolucionarias. Corren los años sesenta y Colombia sufre el desengaño del mesianismo politiquero de Rojas Pinilla. Aparentemente pierde las elecciones presidenciales ante Misael Pastrana Borrero, su rival electoral, quien gobernó entre 1970 a 1974; el pueblo se levanta en protestas en toda la mayoría de las ciudades capitales. "Nos robaron las elecciones", fue el rumor del populacho. Por eso en los años setenta, en el ámbito universitario, afloran las teorías marxistas y en escena aparecen las efigies 
y pensamientos de Lenin, Mao y Trotsky. Es la época de las grandes marchas de protesta para la denuncia de la presencia "gringa" en Colombia, la intromisión del gobierno de Estados Unidos a través de la Alianza para el Progreso, las Brigadas de Paz, el Plan Cáritas, entre otras estrategias, para el control de los destinos económicos, sociales y culturales del Estado colombiano.

En este sentido, los fundadores del M-19 consideran que el robo de las elecciones debe reponerse con la lucha guerrillera. El comandante, de origen samario, Jaime Bateman Cayón, máximo líder del M-19, junto a Iván Marino Ospina y el "Turco" Álvaro Fayad, entre otros, se deciden por la lucha armada y se van "para el monte"; esa era la frase para quien había decidido irse a la guerrilla. Eran hombres de ideales y convencidos de que la revolución se haría con las armas y muy pronto, pues la revolución estaba a la vuelta de la esquina. Al respecto, Burgos Cantor señala que "En medio de la asfixia de estos días, una tarde, me esperaba en la casa Álvaro Fayad. Todavía no le habían puesto su nombre político, el Turco" (2001, p.101). Otra acción revolucionaria del M-19 ocurre el 16 de febrero de 1976 - esta guarda una estrecha relación con el cuento de Burgos Cantor-: es el secuestro del líder sindical de la Confederación de Trabajadores de Colombia (CTC): José Raquel Mercado. Pero, ¿quién era José Raquel Mercado? Era un mulato salido de las entrañas del pueblo, o sea de un barrio marginal de Cartagena, que en la lucha diaria por la vida y de su familia, trabajó como bracero en el Terminal Marítimo. "José Raquel era negro. Tenía la frente ancha y las manos cortas. Es bracero del muelle de la machina" (Burgos Cantor, 1980, p.54). Con una formación académica de cursos elementales, era un asiduo lector. El ejemplo clásico del autodidacta que va puliéndose a la medida que lee, que mejora su escritura, robustece sus conocimientos y desarrolla una oratoria fluida. Como miembro del sindicato del puerto logró llegar a la mesa directiva y algún tiempo después, a la presidencia de la organización sindical. El narrador nos dice que: "José Raquel es negro. Tiene los labios gruesos y los pómulos salientes. Es amigo de todos y los invita a su casa a jugar dominó y oír las canciones" (Burgos Cantor, 1980, p.56). Más adelante nos describe su aspecto físico para acentuar su condición racial: "José Raquel es negro. Tiene el cabello ensortijado y las orejas pequeñas. Él reunió a los cargadores y operadores de elevadores y grúas delante de la oficina del capataz y dijo las peticiones que habíamos acordado" (1980, pp.57-58).

El M-19 sometió a un juicio público la muerte del líder sindical. La gente debía escribir en las paredes un SÍ o un NO y ganó el SÍ, por eso el 19 de abril de 1976 lo asesinaron. Eso nos dice la historia desde la perspectiva de la izquierda 
colombiana. En Lo amador aparece el juego con la palabra y en ella la imagen del cautiverio:

José Raquel era negro. Tiene los ojos cerrados y no sueña. Estuvo en cautiverio durante varios días pero no en la cárcel de San Diego. Lo encerraron en una cárcel sin dirección desde la cual mandaba cartas a sus familiares y hacía análisis sobre la traición. Fue sometido a un proceso popular en el cual los mueleros de la machina votaron porque lo ajusticiaran. (1980, p.64)

"Estas frases de amor que se repiten tanto" es el cuento en donde las palabras que le dan el título dejan al trasluz de la lectura la intención política en el cuento. Esas palabras que se repiten tanto es la convicción de la lucha revolucionaria. Son las voces que engendra el miedo en esos jóvenes idealistas. Este cuento de Roberto Burgos es la metáfora de un hecho histórico en Colombia como es la violencia partidista $\mathrm{y}$, precisamente, estos personajes son hijos de la violencia. Ellos fraguan una forma de vida digna a través de su participación en el destino del país, pero en el cuento, magistralmente, se cierra la perspectiva violenta y como en el cuento "Los asesinos", de Ernest Hemingway, los personajes quedan sumidos en el encierro y en los recuerdos que les atormentan su conciencia revolucionaria. "Esas frases que se repiten tanto" son el sometimiento de la memoria al exorcismo y a la fijeza que otorga la literatura, pues está junto a esa ilusión de un cambio, pues "América Latina se volvió la enorme fosa común de los sueños, ilusiones, deseos, y sangre de una mayoría incalculable" (Burgos Cantor, 2011, p.72), pues tanto el escritor como sus personajes se someten a las evocaciones de una saga sentenciosa, en la cual las voces de la marginalidad nos brindan solo amor por la literatura frente al mundo desarrollado a espaldas del subdesarrollo, como diría Álvaro Tirado Mejía (2014); voces del dolor, voces que brindan una oportunidad de conocer cómo nacen esos personajes en las escuelas del dolor y donde en vez de un sol aparecen las necesidades cotidianas y el pan amargo se cocina diariamente en el fracaso y la ilusión.

En conclusión, la obra narrativa de Roberto Burgos Cantor gira en torno a la ciudad y más precisamente a su Cartagena natal. Es bien sabido que la ciudad está contada desde diversas expresiones sociales, culturales e históricas. Burgos Cantor la ficcionaliza en el aspecto histórico a partir de un momento especial como es la Colonia y en ella el tráfico negrero; asimismo, el escritor cartagenero recrea desde otra dimensión estética la ciudad y en ella la vida marginal. Sus personajes viven al vaivén de lo que ofrece la ciudad amurallada y al desdén que 
ofrece el espacio exclusivo de los blancos. Allá en los extramuros sociales, sus personajes mulatos y negros se recogen en las nostalgias y en las estrecheces de los oficios y con ellos las ambiciones. La niña que sueña con ser cantante, la joven que hace rifas para su reinado, el hombre que viaja a Venezuela con la ilusión de sacar a flote su familia o el mundo de cucañas que teje con sus puños un boxeador, componen el desfile de esos personajes marginales que la música y la cultura popular enmarcan en la ciudad, en el trance de lo antiguo a lo moderno, y de ahí las condiciones sociales tan estrechas de estos personajes que integran los cuentos del libro Lo amador. Todas estas expresiones son tratadas desde la estética narrativa y allí se genera el encuentro con ese aspecto social llamado marginalidad en la ciudad.

En conclusión, lo más importante de este trabajo es que los cuentos de este volumen abren las puertas en la obra de Burgos Cantor a un rastreo del pasado de la ciudad con el fin de allí encontrar el duro y pesaroso pasado del negro, de ese hombre conculcado por la visión europeísta del blanco, la cual estuvo sesgada por las pasiones étnicas y por las fuertes concepciones religiosas del catolicismo. En este sentido, Lo amador vislumbra la formación y configuración de unos personajes traídos del África y puestos en estas tierras de América en condiciones de miseria, desplazamiento y opresión moral y física.

En América Latina y El Caribe, el origen más remoto de la exclusión y la segregación por motivos étnicos y raciales se encuentra en la instauración del régimen de conquista y colonización europeo desde el siglo XV. El sometimiento de las poblaciones indígenas y afrolatinas tuvo como objetivo central la incorporación masiva de mano de obra para las faenas agrícolas y mineras que alimentaban a la metrópolis. Los mecanismos utilizados para obtener este contingente productivo se sustentaban en un principio en el denominado "servicio personal" o "encomienda" y en la esclavitud o trabajo forzado. (Bello y Rangel, 2000, p.10)

Por lo tanto, Burgos Cantor asimila esa transformación acelerada de la ciudad, de esa Cartagena que él vivió en su juventud, que fue testigo de los acontecimientos que sacudieron al país como la violencia partidista, el desplazamiento del campo a la ciudad por unos habitantes desposeídos violentamente de sus pequeñas fincas y arrojados a la ciudad para emprender unas nuevas formas de vida. Esa ciudad vista desde la periferia es la antesala a esa ciudad colonial, a esa ciudad del negro sometido al fuego abrasador de la estupidez del blanco, al odio, 
a otras expresiones religiosas, distantes del catolicismo. Asimismo, nos prepara para vivir los ambientes y la atmósfera narrativa, desde la condición del negro, que dominará la magistral novela La ceiba de la memoria (2007).

Lo amador es el tratamiento estético a una condición social de la vida urbana como es la marginalidad, con el fin de establecer unas imágenes de lo que es el ser caribeño desde la música, el amor, y el trabajo. Todo teñido de la fatalidad de ser marginal, pero elevado a la dignidad por el humor o el estoicismo. Los cuentos de este volumen son la contemplación de la ciudad desde afuera, desde la periferia, no importa el dolor o el sufrimiento, pues importa más la vida del barrio, la socialización de las alegrías y las tristezas.

\section{Referencias bibliográficas}

Aristizábal, A. (2009). "Burgos Cantor: El Caribe, patio del cielo y la tierra. (Anotaciones sobre la primera etapa de su obra)". En: Castillo, Ariel y Urrea, Adriana (Comp.). Roberto Burgos Cantor. Memoria sin guardianes. Bogotá: Ministerio de Cultura-Cartagena, Observatorio del Caribe colombiano.

Bello, Á. y Rangel M. (2000) Etnicidad, raza y equidad en América Latina. Santiago de Chile: CEPAL.

Burgos Cantor, R. (1980). Lo amador. Bogotá: Instituto Colombiano de CulturaUniversidad de Cartagena.

Burgos Cantor, R. (1984). El patio de los vientos perdidos. Bogotá: Editorial Planeta.

Burgos Cantor, R. (1986). Lo amador y otros cuentos. (Segunda edición). Bogotá: Editorial Oveja Negra.

Burgos Cantor, R. (2011). Señas particulares. Bogotá: Editorial Norma.

Burgos Cantor, R. (2012). Lo amador. (Tercera edición). Bogotá: Editorial Planeta.

Calvino, Í. (1999). Las ciudades invisibles. Madrid: Unidad Editorial.

Diccionario de Americanismos (2010). Lima: Asociación de Academias de la Lengua.

Espinosa, A. (2010). Lexicón del carnaval de Barranquilla. Barranquilla: Editorial UniAutónoma.

Fernández, M. (1988). "Una teoría de la humorística”. En: M. E. Mudrovic (Comp.), Espejo en el camino. México: Universidad Nacional Autónoma de México.

Hoffmann, R., García, Mercado y Uribe (1969). "La marginalidad urbana". DESAL, Marginalidad urbana. Santiago de Chile, DESAL, Barcelona: Edi- 
torial Herder.

Martínez, F. (2011). Marginalidad, pobreza y exclusión urbana Obstáculos para la integración social en el hábitat. Revista Arquitectura y Urbanismo, XXXII, 67-72.

Olaciregui, J. (2009). "Roberto Burgos Cantor. El hombre que escribe historias para alejar el miedo". En: Castillo, Ariel y A. Urrea (Comp.), Roberto Burgos Cantor. Memoria sin guardianes. Bogotá: Ministerio de Cultura-Cartagena, Observatorio del Caribe colombiano.

Portaccio Fontalvo, J. (2004). Ochenta años de la Sonora Matancera. Bogotá: Disformas Triviño.

Santana, S. (1999). Benny Moré, hoy como ayer. Medellín: Ediciones Rumbantana

Tirado Mejía, Á. (2014). Los años sesenta. Una revolución en la cultura. Bogotá: Editorial Debate.

Valle, A. (2007). "Marginalidad y ética de la marginalidad en la nueva ciudad narrada por la novela negra latinoamericana". En: Anales de Literatura Hispanoamericana, 36, 95-101. Madrid: Universidad Complutense de Madrid.

Cómo citar este artículo: Motato, H. (2017). Voces de la marginalidad en Lo amador, de Roberto Burgos Cantor. Cuadernos de Literatura, (25), 51-71. DOI: http:// dx.doi.org/10.15648/cl.25.2017.4 